\title{
CSR Performance, Executive Compensation Incentive and Innovation Investment of Chinese Private Enterprises under Dynamic Perspective
}

\author{
Lu He $(i)$ and Minghui Jiang \\ School of Economics and Management, Harbin Institute of Technology, Heilongjiang, Harbin, 150000, China \\ Correspondence should be addressed to Minghui Jiang; jiangminghui@hit.edu.cn
}

Received 27 December 2021; Accepted 8 January 2022; Published 14 February 2022

Academic Editor: Fazli Wahid

Copyright (C) $2022 \mathrm{Lu} \mathrm{He}$ and Minghui Jiang. This is an open access article distributed under the Creative Commons Attribution License, which permits unrestricted use, distribution, and reproduction in any medium, provided the original work is properly cited.

\begin{abstract}
Based on social exchange theory, signal transmission theory and enterprise life cycle theory, this paper empirically analyzes the impact of CSR performance on enterprise innovation investment by taking the A-shares listed private enterprises in Shanghai and Shenzhen stock markets from 2009 to 2019 as research samples. At the same time, we pay attention to the moderating effect of executive compensation incentive, explore the dynamics of the influence mechanism in different life stages. The results show that: there is a significant positive correlation between CSR performance and enterprise innovation investment, that is, CSR behavior is conducive to the improvement of enterprise innovation investment intensity; Executive compensation incentive has a negative moderating effect on this relationship. The higher the incentive level of executive compensation, the weaker the positive impact of CSR performance on innovation investment. Further research shows that CSR performance affects innovation investment through the exchange of government resources and the promotion of market position, but the effects are different during the enterprise life cycle. Relevant conclusions enrich the theory and practice of CSR performance and enterprise innovation investment from the dynamic perspective, provide a theoretical basis for private enterprises to develop a reasonable and effective executive compensation incentive system.
\end{abstract}

\section{Introduction}

Over the past 40 years of reform and opening up, private enterprises have developed rapidly into an important part of the main body of China's market economy. "The 14th FiveYear Plan is the first critical five years for China to move into the forefront of innovative countries. Entering a new stage of development, private enterprises are naturally nested in social networks while growing at high speed, and should strengthen their responsibility to maximize economic, social and environmental values. 2020 December, the Opinions of the State Council of the CPC Central Committee on Creating a Better Development Environment to Support the Reform and Development of Private Enterprises" was released to the public, which clarifies the core position of innovation in the overall situation of China's modernization and proposes a series of policy measures to promote the transformation and upgrading of private entities. Therefore, it is important to strengthen the sense of social responsibility of private enterprises, stimulate the entrepreneurial spirit, and promote greater investment in innovation to accelerate the transformation of our economy into a high-quality development track [1].

In reality, with the continuation of various political, economic and social crises triggered by global COVID-19, Corporate Social Responsibility (CSR) is increasingly expected to become a management model and a strategic factor for change, and is effectively integrated into the management philosophy and business behavior of private entrepreneurs. According to the Blue Book on CSR in China (2020), the Social Responsibility Development Index of the Top 100 Private Enterprises is 29.3 points, an increase of 3.3 points compared to 2019. At the same time, the investment in R\&D activities by private enterprises in 2020 has increased significantly, with more than $24 \%$ of the top 500 private enterprises having a ratio of R\&D personnel greater than $10 \%$ and more than $12 \%$ having an 
R\&D investment intensity of more than $3 \%$. This indicates that private enterprises in China are still making high intensity R\&D investments while achieving high intensity CSR fulfillment. Fostering innovative enterprises require both positive external conditions and enhanced internal dynamics. Through strategic CSR fulfillment, this paper argues that companies will increase their innovation efforts in two ways: first, by shaping a favorable external corporate environment based on relationships, reputation and trust, including the market environment and political environment. In The Structure of Sociological Theories, sociologist J.H. Turner argues that all human social activities are a type of exchange, and that companies reach an implicit contract in the process of interacting with the market and the government, i.e., maintaining each other's interests. CSR fulfillment, as a way of behavior for enterprises to win the approval of the public and the government and to meet the requirements of the market and the expectations of the government, is precisely to develop and consolidate this contract. Based on resource dependency theory and social exchange theory, some scholars argue that CSR fulfillment is an important means for enterprises to "exchange" scientific and technological resources with the government to improve innovation performance [2], and some scholars argue that the extension effect generated by enterprises in practicing CSR behavior can drive enterprise innovation [3], by accumulating more social capital, such as a good positive image and increased consumer and investor confidence in products to improve corporate social prestige [4], prompting firms to enhance their $\mathrm{R} \& \mathrm{D}$ efforts. The second is to shape an effective internal governance mechanism based on incentives and supervision; both CSR fulfillment and innovation R\&D require long-term large-scale investment of resources, and the decision-making role played by corporate executives cannot be ignored [5]. High-order theory suggests that the executive team is the leader of enterprise strategic planning and implementation, holding the allocation mode and strategic orientation of limited resources of the enterprise, and reasonable incentives for executive members can promote strategy implementation more effectively [6], but in fact, a large number of private enterprises do not pay enough attention to executive incentives [7]. Effective incentives can improve the motivation of executives to work, however, a study by Chen, Jian-Lin, and Wen, Zheng-Jie [8] for family firms concluded that aggressive compensation incentives for executives weakened executives' attention to non-financial indicators of CSR, i.e., the tendency of CSR behavior in family firms would be weakened. Therefore, with the continuous improvement of internal governance mechanisms in private firms, it remains to be explored how executive compensation incentives as an important organizational factor affects the relationship between CSR fulfillment and innovation investment.

The findings of the existing empirical literature on the relationship between CSR fulfillment, executive compensation incentives and innovation investment are inconsistent, and this paper suggests that this may be related to the different life cycles in which firms are located. Most of the known studies are based on the static level, ignoring the fact that firms are in a dynamic process of change. When firms are in different life stages, the impact of CSR fulfillment on innovation investment may also show differences. To this end, this paper introduces the real-life situational factor of enterprise life cycle, focuses on private enterprises, combines the external environment shaping and internal incentive mechanism, and explores the dynamic relationship between CSR fulfillment and innovation investment from government perspective and market perspective, with a view to enriching the theory and practice of internal corporate governance and providing reference for private enterprises to dynamically adjust management incentives and CSR policies, which has certain practical significance. This paper focuses on the following questions: 1 . What is the impact of CSR fulfillment on innovation investment? 2. Does executive compensation incentive have a moderating effect on the relationship between CSR fulfillment and innovation investment? 3. If CSR fulfillment can enhance innovation investment, what is the path mechanism through which it works? 4. Do they hold true?

\section{Theoretical Basis and Research Hypothesis}

CSR behavior refers to "the policies, procedures, and behaviors of a company that improve the overall quality of life in society and strive to foster positive relationships with key stakeholders such as employees, customers, and communities" [9], and is as much a part of a company's growth process as its innovation strategy. According to social exchange theory, all human social activities are a kind of exchange. For enterprises, CSR performance, as a behavioral activity that can win the recognition of the public and the government and meet the requirements of the market and government expectations, also has the nature of social exchange, and its purpose is to seek a mutually beneficial symbiotic relationship with the external environment and the organization. On the one hand, CSR activities by enterprises can serve as a complementary channel to compensate for the lack of government investment in public goods and services and reduce financial pressure, so naturally, the government will facilitate the allocation of social resources to these enterprises; on the other hand, the good reputation of CSR activities by enterprises sends a signal to the market that they are doing well, which gives them an advantage in obtaining development resources. The good reputation of the company's CSR activities on the other hand sends a signal to the market that the company is doing well, which makes the company more advantageous in obtaining development resources. While external enabling conditions are important, internal governance is equally important. No improvement in the external environment can replace the internal governance of a company. Executives who have a good internal incentive system will have a strong intrinsic interest in R\&D and innovation, and will be more enthusiastic about integrating and optimizing the resources available to them to achieve higher levels of innovation.

To facilitate the analysis, this paper integrates the perspectives of external environment shaping and internal incentive mechanism, and the logical framework is shown in Figure 1. 


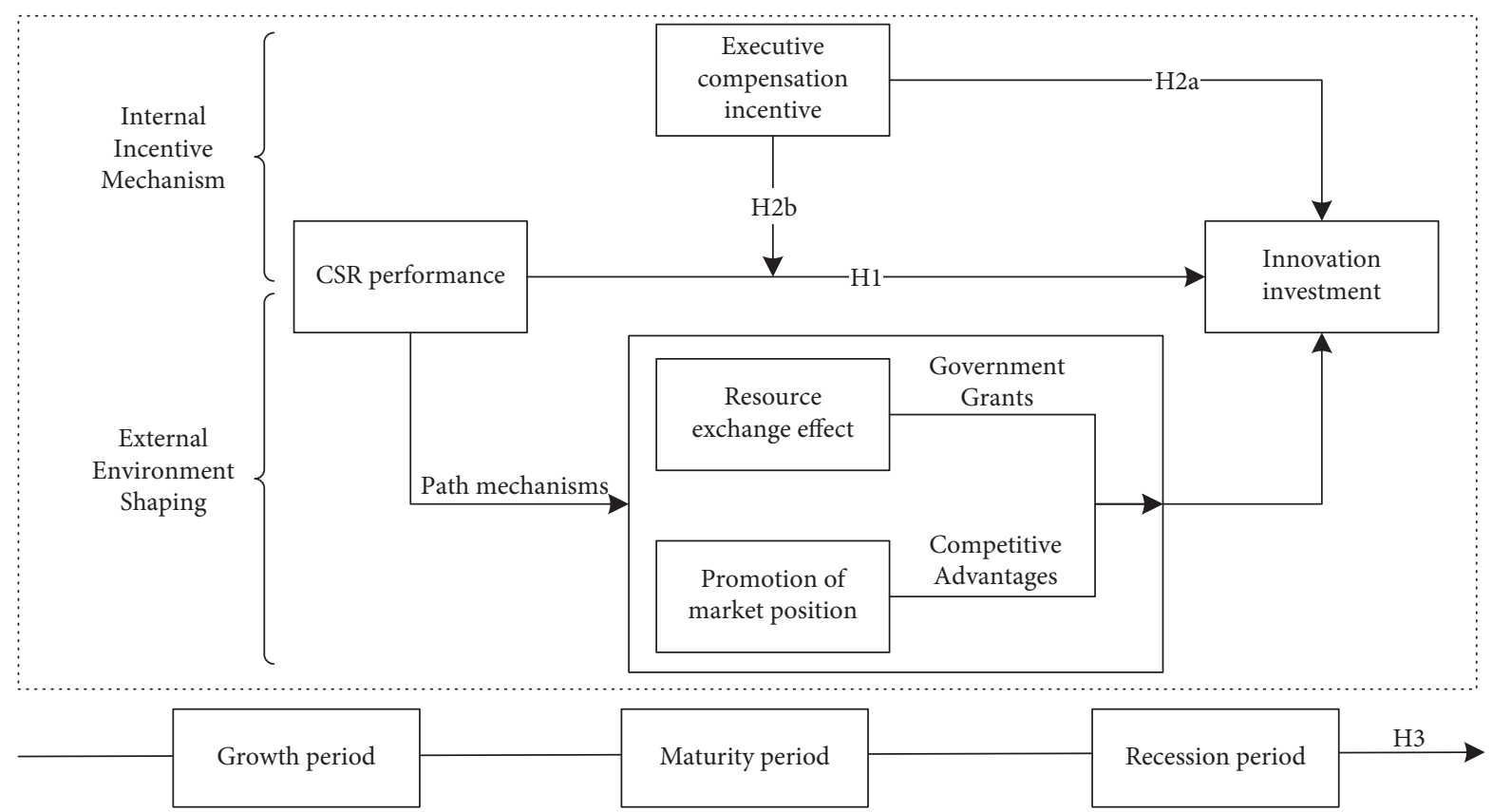

FIGURE 1: The logic analysis framework of CSR performance, executive compensation incentive and innovation investment

2.1. CSR Performance and Innovation Investment. Regarding CSR fulfillment and corporate innovation, some scholars believe that companies that actively fulfill CSR are more likely to make their employees, customers, and society satisfied and loyal to the company, thus establishing deeper social network relationships with internal and external stakeholders at all levels [10] and forming two-way interest interactions. In addition, when stakeholders share information, knowledge, and resources with enterprises, these tangible and intangible assets can enrich the internal resource pool of enterprises and improve their ability to respond to changes in the external environment [11], which helps enterprises establish their own advantages in the market technology competition and thus promote enterprise innovation [12]. Based on this, this paper argues that CSR fulfillment may influence firms' innovation investment through two paths.

One is the government resource exchange effect. In order to achieve innovation goals, leveraging more external resources is an effective way for enterprises to complement their strengths and enhance their investment in innovation. At present, China is in a critical period of the transformation of old and new dynamics, and government departments hold the right to allocate key resources such as funds, land and policies. Enterprises naturally hope to meet the expectations and requirements of the government with certain practical actions, and establish and strengthen interactive relationships with government departments in order to obtain more quality resources and promote innovation decisions. For the government, CSR activities initiated by enterprises create more externalities and contribute to the improvement of regional economic and social culture development and the promotion of "building and sharing together", which is obviously the situation the government wants [13]. At the same time, it can effectively make up for the shortage of public goods and alleviate the economic burden of the government, which is a win-win outcome for the mutual needs of the government and enterprises [14]. In return for the reciprocal exchange, when the enterprises meet the needs of the government, the government will show positive attitudes and behaviors by granting these enterprises with convenient conditions. Some scholars, based on resource dependence theory and social exchange theory, argue that private enterprises can exchange resources with the government to obtain credit inclination [15], tax incentives [16], and government subsidies [17] through philanthropic behavior, which help to reduce the cost of innovation R\&D and motivate enterprises to invest in innovation [18]. Therefore, under the framework of mutually beneficial social exchange theory, CSR fulfillment can maintain a reciprocal relationship with the government, which is beneficial for enterprises to receive government subsidies and achieve resource exchange, thus providing a more favorable environment for enterprise development and increasing innovation investment.

Secondly, market dominance is taken. According to the "strategic philanthropy" viewpoint $[19,20]$, enterprises have the intention to conduct CSR activities for long-term development strategy and to better enhance the organization's image and business performance. According to the signaling theory, good CSR performance is a positive signal to the market [21], which indicates that the company has a good financial status and a complete sense of responsibility. After this positive signal is digested by the market, it can, on the one hand, enhance the reputation of the media and industry for the company, strengthen the reputation of brand significance [22], deepen the social identity of the organization [23], and then improve the external competitive position of the company, obtain more excess revenue, and guarantee the company has a continuous flow of funds to promote 
innovation investment [7]; on the other hand, it helps to alleviate the information asymmetry between external investors and the company degree, reduce investment risks, win more investors' favor, make them more inclined to invest in donor enterprises, and form a sustainable competitive advantage [24]. At the same time, the market position advantage of enterprises helps broaden the information resource exchange channel, which is conducive to attracting better professionals [25], prompting enterprises to improve their internal management. The return of these intangible resources in the market helps companies to establish their own advantages in the market competition and drive up the level of innovation input.

Based on the above analysis, this paper proposes the following research hypotheses.

$\mathrm{H} 1$ : CSR fulfillment is conducive to increasing private enterprises' innovation investment efforts.

\subsection{Executive Compensation Incentive, CSR Performance and} Innovation Investment. Proper incentive can improve the intrinsic motivation of enterprise development. Executives have an important position in the strategic decision-making of enterprises, and directly determine the allocation of resources and innovation investment decisions. The separation of property rights and management rights in modern enterprises has triggered principal-agent conflicts, and executive incentives are generally considered as an effective means that can mitigate moral hazard and are one of the factors that influence executives' investment decision behavior, of which compensation incentives are the most direct form of incentives [26]. Short-term compensation incentives are low-risk and quite attractive, and if a company's profits are highly correlated with its own compensation level, it is natural for executives to care more about the company's interests and pay more and more attention to innovative investments. Gu Feng et al [27] studied that the development of a compensation incentive system in companies can increase the motivation of management to carry out innovation, which in turn increases the $\mathrm{R} \& \mathrm{D}$ investment of the company. In this sense, compensation incentives for management are conducive to increasing firms' investment in innovation.

However, as the actual operators of the firm, when executives themselves have high annual salaries, the more power they have in the firm accordingly, which leads to the fact that executive compensation incentives are not always effective [28], and if they are not well supervised, they are likely to maximize their own interests to the detriment of other shareholders. According to principal-agent theory, the asymmetry in shareholders' access to information leads to incomplete control over the intentions of corporate managers, which provides the possibility of self-interest motives for management. On the one hand, the short-term contractual nature of compensation incentives may lead executives to make risk-averse decisions, making them reluctant to perform CSR activities and innovation R\&D projects at the same time, or to choose to reduce the amount of innovation investment after the normal performance of CSR activities in order to maximize their own predictable benefits. On the other hand, with the increase in executive compensation, executives are materially secured in the short term and thus are bound to consider whether it is beneficial to continue to increase their own interests when making subsequent decisions. However, CSR activities reduce a company's own cash flow, and management, as a rational economic person, may choose to cut spending on CSR activities to maintain corporate resources for internal turnover, consolidate vested interests, ensure the steady progress of existing innovation projects, and prevent excessive investment in CSR activities from affecting the favorable position established at this time. The reduction in CSR fulfillment, on the other hand, will undoubtedly affect the extent to which CSR enhances innovation investment [7].

In summary, this paper proposes the following research hypothesis.

$\mathrm{H} 2 \mathrm{a}$ : Executive compensation incentives are beneficial to increase innovation investment in private firms.

$\mathrm{H} 2 \mathrm{~b}$ : Executive compensation incentives negatively moderate the relationship between CSR fulfillment and private firms' innovation investment.

2.3. Dynamic Analysis Combined with Enterprise Life Cycle Characteristics. Based on the theory of enterprise life cycle, enterprises are life-like organizations, and the production and organizational characteristics of enterprises at different stages of their life cycle differ greatly, which require a variation of business strategies. Generally speaking, CSR fulfillment, executive motivation and innovation investment cover all stages of corporate growth, but the degree of need is different at specific stages. In addition, the self-interest motivation of management varies in different stages of business operation, and firms have to face different agency problems [29]. Based on this idea, it is necessary to examine the relationship between the three by matching the firm characteristics that are revealed in different life stages of the firm.

When in the introduction and growth period, the company's products have just entered the market, sales revenue is low, the main problem faced by the company is uncertainty, and at this time, the company has not yet formed a clear incentive system of rewards and punishments, and on the one hand, to develop the market, but also to invest in production operations, internal resources are very tight. However, both innovation activities and CSR fulfillment require resources, and if resources are certain, fulfilling CSR activities means lower resource investment in innovation. Therefore, the relationship between CSR fulfillment, executive compensation incentives and innovation investment is not obvious for enterprises in the introduction and growth stages, and the path mechanism of resource exchange effect and market position improvement is likely to be ineffective.

Companies in the mature stage have more stable market position and profits, consolidated competitive advantages in the market, expanded influence and increased sales revenue, 
which provide the strength for CSR activities. And there is sufficient cash flow and low uncertainty to support innovation investment. Zhang Zengang et al [2] pointed out that organizational redundancy enhances a firm's ability to obtain market and government resources back through socially responsible behaviors such as donations, which in turn enhances innovation performance. However, at the same time, a stable flow of funds to the firm exposes management to greater autonomy in making investment decisions, which exacerbates the firm's agency problem [30].Narayanan also argues that when management has the power to make many of the firm's investment decisions, they will take as much of their own interests into account as possible in their decisions [31]. Free cash flow agency theory suggests that when firms have sufficient free cash flow, managers tend to invest this cash in inefficient investment projects that would create private benefits for themselves [32]. Therefore, this paper predicts that CSR fulfillment by firms in the maturity stage will play a facilitating role in innovation investment, when the path mechanism of resource exchange effect and market position enhancement holds. Executive compensation incentives negatively affect the positive relationship between CSR fulfillment and innovation investment.

In the recession stage, although the company may still have a huge market share, the loss of resources and performance decline lead to tight capital flow, the proportion of fixed expenses in total expenses increases, the business risks gradually rise, and internal agency problems intensify. In this stage, executives start to think more about their own career development plans and are usually more prudent in their investment decisions to protect their own interests and reduce investment risks for the sake of job preservation and reputation protection, so as to reduce CSR activities, lower innovation investment or even stop investing, as much as possible. The status quo is maintained, although these investment opportunities may allow the firm to be reborn $[33,34]$. Therefore, this paper predicts that executive compensation incentives of firms in decline still negatively affect the positive relationship between CSR performance and innovation investment.

The above analysis shows that at different stages of the life cycle, in order to adapt to the environment, firms exhibit different characteristics in their business activities and strategic choices, and the corresponding agency costs vary, resulting in dynamic changes in both CSR fulfillment and innovation investment. Based on this, the following hypotheses are proposed.

H3: The relationship among CSR fulfillment, executive compensation incentives, and innovation investment is dynamically different when firms are in different life cycle stages.

H3a: At the stage of maturity, CSR fulfillment of a company will play a facilitating role in innovation investment.

H3b: Executive compensation incentives negatively affect the relationship between CSR fulfillment and innovation investment in both maturity and decline stages of the firm.
H3c: CSR fulfillment promotes the increase of innovation investment in firms through the resource exchange effect is established in firms in the maturity stage.

H3d: CSR fulfillment promotes the increase of firm's innovation investment through market position enhancement is established in firms in the maturity stage.

\section{Study Design}

3.1. Sample Selection and Data Sources. This paper selects private enterprises listed on the main board of Shanghai and Shenzhen A-shares in China from 2009 to 2019 as the research sample, and selects them based on the following principles: (1) excluding financial listed companies, which are usually eliminated in view of their business not being comparable; (2) eliminating $\mathrm{ST}, \mathrm{PT}$ and $* \mathrm{ST}$ enterprises during the sample period; (3) eliminating companies whose corporate governance and financial data are not publicized; (4) manually entering the information by checking the annual reports of listed companies, relevant The information that is missing is entered manually by checking the annual reports of listed companies, relevant announcements and searching the internet. The final unbalanced panel data containing 6204 observation samples were obtained, among which corporate financial and corporate governance data were mainly obtained from Guotaian database, RESSET database and CNRDS China Research Data Service Platform, and CSR data were obtained from Hexun.com database. The data from different channels were compared and verified to confirm the reliability.

\subsection{Variable Selection}

(1) Dependent Variable. The innovation investment (RDI) indicator is measured by the ratio of total corporate $R \& D$ investment to operating revenue. The relevant data are compiled from the R\&D innovation column of listed companies in the CSMAR database, and some missing values are filled in by manually extracting from the annual reports of listed companies.

(2) Independent Variables. The CSR indicator is selected to represent the performance of enterprises by the total CSR evaluation score of listed companies published by Hexun.com. The score measures five dimensions of corporate shareholder responsibility, customer and consumer responsibility, supplier and employee responsibility, environmental responsibility and social responsibility, and contains 13 secondary indicators and 37 tertiary indicators, and the total score reflects the degree of CSR fulfillment of each enterprise in an objective way. The higher the score, the better the CSR performance of the company. At present, this data has been used as an important basis for some domestic scholars to measure CSR behavior [10, 11, 35], which has certain authority and reasonableness. 
(3) Moderating Variables. Executive compensation incentives $(\operatorname{Ln} P A Y)$. Referring to related studies [29], the total annual salary of corporate executives is measured by taking the natural logarithm.

(4) Path test. Corporate government subsidies ( $L n G O V$ ). Referring to previous literature, the total amount of government grants obtained in the year disclosed in the company's annual report was used to take the natural logarithm for measurement.

Corporate market position $(\mathrm{Pcm})$. In this paper, we choose the Lerner index to measure the enterprise market position, referring to Peress [36], defining the Lerner index as the firm's (operating revenue - operating costs - selling expenses - administrative expenses)/operating revenue, to which the industry average price-cost margin is subtracted to control for structural differences between industries that are not related to the degree of competition. The higher the value the stronger the pricing power of the company in the market, and the higher the dominant position of the company in the market.

(5) Corporate life cycle grouping. In order to further study the above relationship, this paper divides the enterprises into different life cycles for further analysis. There is no unified conclusion on the classification of life cycle, but it can be divided into three categories: univariate analysis (e.g., firm size and age), financial composite index method (Anthony and Ramesh, 1992) and cash flow model method (Dickinson, 2011). Compared with the first two, the cash flow portfolio of an enterprise reflects the various characteristics of the enterprise's internal operating capacity, ability to raise funds, and the way of using funds, which can clearly and objectively reflect the complex operating activities of the enterprise. Therefore, this paper draws on Dickinson's treatment by taking the sign of a firm's net cash flow from operating activities, net cash flow from investing activities, and net cash flow from financing activities (the sign takes "_" when the net cash flow is negative and "+" when the net cash flow is positive") are combined to classify the life cycle stage in which the company is located [37], and are integrated on this basis. Dickinson classifies the life cycle of an enterprise into five stages: start-up, growth, maturity, turbulence and recession. In this paper, referring to the related literature [38], enterprises in the growth stage are set to have positive cash flow from financing activities and negative cash flow from investing activities. Then, according to the characteristics of the turbulent period samples, the samples in the turbulent period whose characteristics tend to mature are grouped into the mature period group, and the samples whose characteristics tend to recession are grouped into the recession period group. Finally, we get the three stage groupings of growth period, maturing period and recession period delineated in this paper, as shown in Table 1.

(6) Control variables. In addition to the core variables mentioned above, three control variables are set for enterprise characteristics, governance structure, and financial status to ensure the stability of the model. Among them, firm characteristics include firm age (AGE) and size (LnA). The governance structure factor is controlled by the size of the board of directors (BOA), the shareholding ratio of the first largest shareholder (Share1), and the equity checks and balances (Balance), drawing on relevant studies such as Chen Dong [39]. The financial status factors are controlled by reference to previous literature [7, 25], and corporate value (Tobin's Q), return on equity (ROE), firm growth (Irr), and cash flow (CF) are selected. In addition, year (YEAR) and industry (IND) dummy variables are also set in the model. The specific variables are described in Table 2.

3.3. Model Construction. In order to verify the relationship between CSR fulfillment and corporate innovation investment, model (1) is constructed in this paper as follows.

$$
\begin{aligned}
R D I_{i t}= & \alpha_{0}+\alpha_{1} C S R_{i t}+\alpha_{2} A_{G E_{i t}}+\alpha_{3} \text { LnA }_{i t} \\
& +\alpha_{4} \text { BOA }_{i t}+\alpha_{5} \text { Share }_{i t}+\alpha_{6} \text { Balance }_{i t}+\alpha_{7} \text { Tobin's }_{i t} \\
& +\alpha_{8} R O E_{i t}+\alpha_{9} \text { Irr }_{i t}+\alpha_{10} C_{i t}+\sum Y E A R \\
& +\sum P R O V+\sum I N D+\varepsilon .
\end{aligned}
$$

In order to investigate the relationship between CSR fulfillment, executive compensation incentives and innovation investment, model (2) is constructed in this paper as follows. The main explanatory variables are executive compensation incentives ( $\operatorname{Ln} P A Y)$ and the interaction term between executive compensation incentives and $\operatorname{CSR}(C S R * \operatorname{Ln} P A Y)$. The variables in the interaction term are centralized.

$$
\begin{aligned}
R D I_{i t}= & \alpha_{0}+\alpha_{1} C S S R_{i t}+\alpha_{2} \operatorname{LnPAY} Y_{i t}+\alpha_{3} C R_{i t} * \operatorname{LnPAY} Y_{i t} \\
& +\alpha_{4} A G E_{i t}+\alpha_{5} \operatorname{LnA}_{i t}+\alpha_{6} B O A_{i t}+\alpha_{7} \text { Share }_{i t} \\
& +\alpha_{8} \text { Balance }_{i t}+\alpha_{9} \text { Tobin's }_{i t} \\
& +\alpha_{10} \text { ROE }_{i t}+\alpha_{11} \text { Irr }_{i t}+\alpha_{12} C_{i t}+\sum Y E A R \\
& +\sum I N D+\sum P R O V+\varepsilon .
\end{aligned}
$$

\section{Empirical Results and Analysis}

4.1. Descriptive Statistics and Correlation Analysis. Table 3 shows the descriptive statistics of the main variables. From the case of the explanatory variables, the mean value of innovation input $(R D I)$ is 3.608 with a standard deviation of 4.031 , indicating that the current level of innovation input of listed private enterprises is low overall, and the variability is not significant. In terms of explanatory variables, the mean value of CSR is 25.79, indicating that the overall CSR score of currently listed private enterprises is low, with a maximum value of 90.24 , a minimum value of -5.92 , and a standard deviation of 13.77, indicating that the differences in CSR fulfillment among different enterprises are more obvious, and there are large fluctuations among different enterprises. In addition, in terms of executive incentives, the mean and standard deviation of executive compensation incentives $(L n P A Y)$ are 15.21 and 0.899 , respectively, indicating that the level of executive compensation incentives is higher in different enterprises and the differences are not significant.

Table 4 shows the results of the correlation analysis of the variables. From the results of correlation coefficient of each variable, the correlation coefficient between CSR and 
TABle 1: Classification standard of enterprise life cycle.

\begin{tabular}{|c|c|c|c|c|c|c|c|c|}
\hline $\begin{array}{l}\text { This article on business } \\
\text { lifecycle segmentation }\end{array}$ & \multicolumn{2}{|c|}{ Growth period } & \multicolumn{3}{|c|}{ Maturity period } & \multicolumn{3}{|c|}{ Recession period } \\
\hline $\begin{array}{l}\text { Dickinson Enterprise } \\
\text { Lifecycle Segmentation }\end{array}$ & $\begin{array}{l}\text { Start-up } \\
\text { period }\end{array}$ & $\begin{array}{l}\text { Growth } \\
\text { period }\end{array}$ & $\begin{array}{c}\text { Maturing } \\
\text { period }\end{array}$ & $\begin{array}{c}\text { Turbulent } \\
\text { period }\end{array}$ & $\begin{array}{c}\text { Turbulent } \\
\text { period }\end{array}$ & $\begin{array}{c}\text { Turbulent } \\
\text { period }\end{array}$ & $\begin{array}{c}\text { Recession } \\
\text { period }\end{array}$ & $\begin{array}{c}\text { Recession } \\
\text { period }\end{array}$ \\
\hline $\begin{array}{l}\text { Net cash flow from } \\
\text { operating activities }\end{array}$ & - & + & + & - & + & + & - & - \\
\hline $\begin{array}{l}\text { Net cash flow from } \\
\text { investing activities }\end{array}$ & - & - & - & - & + & + & + & + \\
\hline $\begin{array}{l}\text { Net cash flow from } \\
\text { financing activities }\end{array}$ & + & + & - & - & + & - & + & - \\
\hline
\end{tabular}

TABLE 2: Definition of the variables.

\begin{tabular}{|c|c|c|}
\hline Variable name & $\begin{array}{l}\text { Variable } \\
\text { symbol }\end{array}$ & Variable definition \\
\hline Innovation investment & RDI & R\&D investment expenses/operating revenue \\
\hline CSR performance & CSR & Hexun.com on Corporate Social Responsibility Ratings \\
\hline $\begin{array}{l}\text { Executive compensation } \\
\text { incentive }\end{array}$ & LnPAY & Natural logarithm of total annual salary of senior executives \\
\hline Enterprise government subsidy & LnGOV & $\begin{array}{c}\text { Natural logarithm of the total amount of government subsidies received by the } \\
\text { enterprise in the year }\end{array}$ \\
\hline $\begin{array}{l}\text { Competitive position of } \\
\text { enterprises }\end{array}$ & Pcm & Lerner index at firm level - Lerner index at industry level \\
\hline Enterprise age & AGE & $\begin{array}{l}\text { The establishment period of a listed company is the number of years from the } \\
\text { establishment of the listed company to the sample examination year }\end{array}$ \\
\hline Enterprise scale & $\operatorname{Ln} A$ & Natural logarithm of total assets at the end of the period \\
\hline Board size & $\mathrm{BOA}$ & Number of board members \\
\hline $\begin{array}{l}\text { Shareholding ratio of the largest } \\
\text { shareholder }\end{array}$ & Share1 & $\begin{array}{c}\text { Proportion of the number of shares held by the largest shareholder in the total share } \\
\text { capital }\end{array}$ \\
\hline Equity checks and balances & Balance & $\begin{array}{c}\text { The sum of the shareholdings of the second to tenth largest shareholders / the } \\
\text { shareholding of the first largest shareholder }\end{array}$ \\
\hline Ente & Tobin's $Q$ & (Market value of stocks + book value of liabilities)/Total assets at the end of the year \\
\hline assets & ROE & Net profit after tax / net assets \\
\hline Company growth & Irr & Growth rate of main business income \\
\hline Cash flow & $\mathrm{CF}$ & Net cash flow from operating activities / total assets at the end of th \\
\hline Year dumn & YEAR & $\begin{array}{c}\text { Controlling the dummy variables for the year, this paper sets the corresponding dummy } \\
\text { variables for each of the } 11 \text { years from 2009-2019 }\end{array}$ \\
\hline Industry dummy variable & IND & Dummy variables for control industries, represented by 21 industry dummy variables \\
\hline Province dummy variable & PROV & $\begin{array}{c}\text { Dummy variables controlling for provinces, expressed as dummy variables for } 34 \\
\text { provincial administrative regions }\end{array}$ \\
\hline
\end{tabular}

TABle 3: Descriptive statistics of main variables.

\begin{tabular}{lccccc}
\hline VARIABLES & $\mathrm{N}$ & mean & $\mathrm{sd}$ & $\min$ & $\max$ \\
\hline RDI & 3,500 & 3.608 & 4.031 & 0 & 48.48 \\
CSR & 5,579 & 25.79 & 13.77 & -5.920 & 90.24 \\
LnPAY & 5,063 & 15.21 & 0.899 & 11.51 & 18.94 \\
AGE & 6,204 & 18.84 & 5.257 & 3 & 61 \\
LnA & 6,203 & 22.15 & 1.358 & 10.84 & 28.34 \\
BOA & 6,183 & 8.526 & 1.714 & 0 & 20 \\
Share1 & 6,183 & 32.76 & 15.32 & 0.286 & 89.41 \\
Balance & 6,183 & 0.945 & 0.849 & 0.00834 & 6.775 \\
TobinsQ & 6,142 & 8.907 & 518.5 & 0.0541 & 40,632 \\
ROE & 6,183 & 0.111 & 0.183 & 0 & 8.670 \\
Irr & 6,183 & 4.388 & 194.1 & -0.997 & 14,883 \\
CF & 6,203 & 0.0462 & 0.169 & -10.22 & 2.457 \\
\hline
\end{tabular}

innovation investment is 0.14 , which is significant at the $1 \%$ level, initially verifying hypothesis 1 , indicating that CSR fulfillment has a facilitating effect on innovation investment. the correlation coefficient between LnPAY and innovation investment is 0.414 , which is significant at the $1 \%$ level, initially verifying hypothesis $\mathrm{H} 2 \mathrm{a}$ : executive compensation incentives are conducive to increasing innovation investment in private enterprises. The absolute values of the correlation coefficients between the variables are less than 0.5 , indicating that there is no multicollinearity problem among the variables. By further calculating the variance inflation factor VIF, we found that its maximum value is 1.95. The next step of regression analysis can be conducted.

\subsection{Regression Analysis}

(1) CSR performance and enterprise innovation investment. In this paper, the model results are analyzed using a mixed OLS regression approach. Table 5 reports the regression results of CSR fulfillment and firms' innovation investment. Among 
TABLE 4: Correlation analysis of main variables.

\begin{tabular}{|c|c|c|c|c|c|c|c|c|c|c|c|c|}
\hline & RDI & CSR & LnPAY & AGE & $\operatorname{Ln} A$ & $\mathrm{BOA}$ & Share1 & Balance & TobinsQ & ROE & Irr & $\mathrm{CF}$ \\
\hline RDI & 1 & & & & & & & & & & & \\
\hline CSR & $0.140^{* * *}$ & 1 & & & & & & & & & & \\
\hline LnPAY & $0.414^{* * *}$ & $0.371^{* * *}$ & 1 & & & & & & & & & \\
\hline AGE & $-0.065^{*}$ & $0.096^{* *}$ & 0.100 & 1 & & & & & & & & \\
\hline $\operatorname{Ln} A$ & $0.173^{* *}$ & $0.338^{* * *}$ & $0.420^{* *}$ & $0.141^{* *}$ & 1 & & & & & & & \\
\hline $\mathrm{BOA}$ & 0.040 & $0.070^{* *}$ & $0.261^{* * *}$ & -0.048 & $0.228^{* *}$ & 1 & & & & & & \\
\hline Share1 & $0.058^{*}$ & $0.117^{* *}$ & $0.048^{*}$ & $-0.109^{* *}$ & $0.169^{* *}$ & $-0.046^{* *}$ & 1 & & & & & \\
\hline Balance & 0.049 & -0.004 & $0.147^{* *}$ & $0.059^{* *}$ & -0.009 & $0.072^{*}$ & $-0.426^{* * *}$ & 1 & & & & \\
\hline TobinsQ & $0.119^{* *}$ & -0.02 & $-0.025^{*}$ & -0.019 & $-0.111^{* *}$ & -0.027 & -0.0170 & $0.027^{*}$ & 1 & & & \\
\hline ROE & 0.0270 & $0.084^{* *}$ & $0.066^{* *}$ & $-0.022^{*}$ & 0.018 & $0.023^{*}$ & $0.062^{* *}$ & 0 & -0.007 & 1 & & \\
\hline Irr & -0.018 & 0.005 & 0.028 & 0.011 & $0.024^{*}$ & -0.001 & 0.001 & 0.024 & 0 & 0.02 & 1 & \\
\hline $\mathrm{CF}$ & $0.041^{*}$ & $0.056^{* * *}$ & $0.065^{* *}$ & $-0.031^{*}$ & $0.059^{* * *}$ & 0.035 & $0.059^{* *}$ & $-0.056^{* *}$ & $0.030^{*}$ & $0.078^{* *}$ & -0.014 & 1 \\
\hline
\end{tabular}

Note. ${ }^{* * *},{ }^{* *}$, and ${ }^{*}$ indicate significant at the $1 \%, 5 \%$, and $10 \%$ levels, respectively.

TABLE 5: Regression results of CSR performance and enterprise innovation investment.

\begin{tabular}{|c|c|c|}
\hline VARIABLES & $\begin{array}{c}(1) \\
\text { RDI }\end{array}$ & $\begin{array}{c}(2) \\
\text { RDI }\end{array}$ \\
\hline$\overline{C S R}$ & & $\begin{array}{c}0.102^{* *} \\
(2.05)\end{array}$ \\
\hline AGE & $\begin{array}{c}-0.026^{* * *} \\
(-5.66)\end{array}$ & $\begin{array}{c}-0.026^{* * *} \\
(-5.63)\end{array}$ \\
\hline $\operatorname{Ln} A$ & $\begin{array}{c}0.843^{* * *} \\
(35.00)\end{array}$ & $\begin{array}{c}0.828^{* * *} \\
(34.24)\end{array}$ \\
\hline $\mathrm{BOA}$ & $\begin{array}{l}-0.006 \\
(-0.42)\end{array}$ & $\begin{array}{l}-0.006 \\
(-0.43)\end{array}$ \\
\hline Share1 & $\begin{array}{l}-0.002 \\
(-0.88)\end{array}$ & $\begin{array}{l}-0.002 \\
(-1.10)\end{array}$ \\
\hline Balance & $\begin{array}{l}-0.003 \\
(-0.06)\end{array}$ & $\begin{array}{l}-0.008 \\
(-0.18)\end{array}$ \\
\hline TobinsQ & $\begin{array}{c}0.077^{* * *} \\
(4.49)\end{array}$ & $\begin{array}{c}0.077^{* * *} \\
(4.50)\end{array}$ \\
\hline ROE & $\begin{array}{c}1.096^{* * *} \\
(3.10)\end{array}$ & $\begin{array}{c}0.853^{* * *} \\
(2.62)\end{array}$ \\
\hline Irr & $\begin{array}{c}-0.002^{* * *} \\
(-12.80)\end{array}$ & $\begin{array}{c}-0.002^{* * *} \\
(-12.69)\end{array}$ \\
\hline $\mathrm{CF}$ & $\begin{array}{c}1.405^{* * *} \\
(3.42)\end{array}$ & $\begin{array}{c}1.253^{* * *} \\
(3.08)\end{array}$ \\
\hline YEAR & Control & control \\
\hline IND & Control & control \\
\hline PROV & Control & control \\
\hline Constant & $\begin{array}{c}-2.953^{* * *} \\
(-4.57)\end{array}$ & $\begin{array}{c}-2.863^{* * *} \\
(-4.47)\end{array}$ \\
\hline Observations & 3,496 & 3,496 \\
\hline $\mathrm{R}$-squared & 0.452 & 0.454 \\
\hline $\mathrm{F}$ test & 0 & 0 \\
\hline Adj_R2 & 0.446 & 0.448 \\
\hline $\mathrm{F}$ & 77.45 & 75.90 \\
\hline
\end{tabular}

them, Model (1) is the regression result without the inclusion of CSR, and Model (2) is the regression result with the inclusion of CSR. It can be seen that after controlling for the relevant variables, the regression coefficient of CSR is 0.071 , which is significant at the $1 \%$ level, indicating that there is a significant positive relationship between CSR fulfillment and firms' innovation investment, which means that the corresponding innovation investment increases with the increase in the level of CSR fulfillment, and hypothesis $\mathrm{H} 1$ is verified. The reason behind this may be that companies focus more on long-term development performance when fulfilling CSR activities, and long-term performance creation needs to be matched with corresponding innovation capability to drive continuous innovation. Moreover, the social capital accumulated by enterprises through CSR activities can be "exchanged" for good relations with the government and more resources to be realized on the one hand, and on the other hand, it helps to take advantage of the market dominance and release positive signals, which are beneficial to increase innovation investment.

(2) Executive compensation incentives, CSR fulfilment and corporate innovation investment. The regression results in Table 6 show that the coefficients of CSR are all significantly positive, indicating that CSR fulfillment has a positive contribution to corporate innovation investment. model (1) results show that executive compensation incentives $(L n P A Y)$ and innovation investment $(R D I)$ have a significant positive relationship $(\beta=0.279, \mathrm{p}<0.01)$, indicating that corporate executive compensation incentives can effectively improve R\&D The hypothesis H2a is verified. In Model (2), the coefficient of $C S R * \operatorname{Ln} P A Y$ is significantly negative $(\beta=-0.078, p<0.01)$, which indicates that the level of executive compensation incentive has a significant negative moderating effect on the relationship between CSR and enterprise innovation investment. has a significant negative moderating effect, i.e., the positive effect of CSR fulfillment on corporate innovation investment is weakened by the increase of executive compensation incentives, and hypothesis $\mathrm{H} 2 \mathrm{~b}$ is verified. Excessive compensation incentives reduce executives' sense of responsibility and are not conducive to CSR fulfillment's enhanced effect on innovation engagement, suggesting that firms should make adaptive strategic adjustments to the existing compensation incentives to address the incentive failure phenomenon. Figure 2 presents this relationship: the higher the level of executive compensation incentives, the less innovation investment firms can increase through CSR fulfillment.

(3) Path analysis. The results of the path analysis are shown in Table 7. According to the above, CSR activities are effective in increasing firms' innovation investment through 
TABLE 6: The moderating effect of executive compensation incentive.

\begin{tabular}{|c|c|c|}
\hline VARIABLES & $\begin{array}{c}(1) \\
\text { RDI }\end{array}$ & $\begin{array}{c}(2) \\
\text { RDI }\end{array}$ \\
\hline CSR & $\begin{array}{c}0.059^{* * *} \\
(2.71)\end{array}$ & $\begin{array}{c}0.093^{* * *} \\
(3.67)\end{array}$ \\
\hline LnPAY & $\begin{array}{c}0.279^{* * *} \\
(5.81)\end{array}$ & $\begin{array}{c}0.333^{* * *} \\
(6.87)\end{array}$ \\
\hline $\mathrm{CSR} * \mathrm{LnPAY}$ & & $\begin{array}{c}-0.078^{* * *} \\
(-2.85)\end{array}$ \\
\hline AGE & $\begin{array}{c}-0.026^{* * *} \\
(-4.53)\end{array}$ & $\begin{array}{c}-0.026^{* * *} \\
(-4.51)\end{array}$ \\
\hline $\operatorname{Ln} A$ & $\begin{array}{c}0.718^{* * *} \\
(19.95)\end{array}$ & $\begin{array}{c}0.716^{* * *} \\
(20.05)\end{array}$ \\
\hline $\mathrm{BOA}$ & $\begin{array}{l}-0.024 \\
(-1.36)\end{array}$ & $\begin{array}{l}-0.024 \\
(-1.37)\end{array}$ \\
\hline Share1 & $\begin{array}{l}-0.002 \\
(-0.82)\end{array}$ & $\begin{array}{l}-0.003 \\
(-0.98)\end{array}$ \\
\hline Balance & $\begin{array}{l}-0.024 \\
(-0.44)\end{array}$ & $\begin{array}{l}-0.024 \\
(-0.46)\end{array}$ \\
\hline TobinsQ & $\begin{array}{c}0.064^{* * *} \\
(3.31)\end{array}$ & $\begin{array}{c}0.064^{* * *} \\
(3.34)\end{array}$ \\
\hline $\mathrm{ROE}$ & $\begin{array}{c}0.627^{*} \\
(1.95)\end{array}$ & $\begin{array}{l}0.619^{*} \\
(1.94)\end{array}$ \\
\hline Irr & $\begin{array}{c}-0.002^{* * *} \\
(-12.48)\end{array}$ & $\begin{array}{c}-0.002^{* * *} \\
(-12.12)\end{array}$ \\
\hline CF & $\begin{array}{c}1.503^{* * *} \\
(3.25)\end{array}$ & $\begin{array}{c}1.438^{* * *} \\
(3.14)\end{array}$ \\
\hline YEAR & control & control \\
\hline IND & control & control \\
\hline PROV & control & control \\
\hline Constant & $\begin{array}{c}-4.266^{* * *} \\
(-5.11)\end{array}$ & $\begin{array}{c}-5.170^{* * *} \\
(-6.14)\end{array}$ \\
\hline Observations & 2,559 & 2,559 \\
\hline R-squared & 0.440 & 0.443 \\
\hline F test & 0 & 0 \\
\hline Adj_R2 & 0.432 & 0.435 \\
\hline F & 55.73 & 56.55 \\
\hline
\end{tabular}

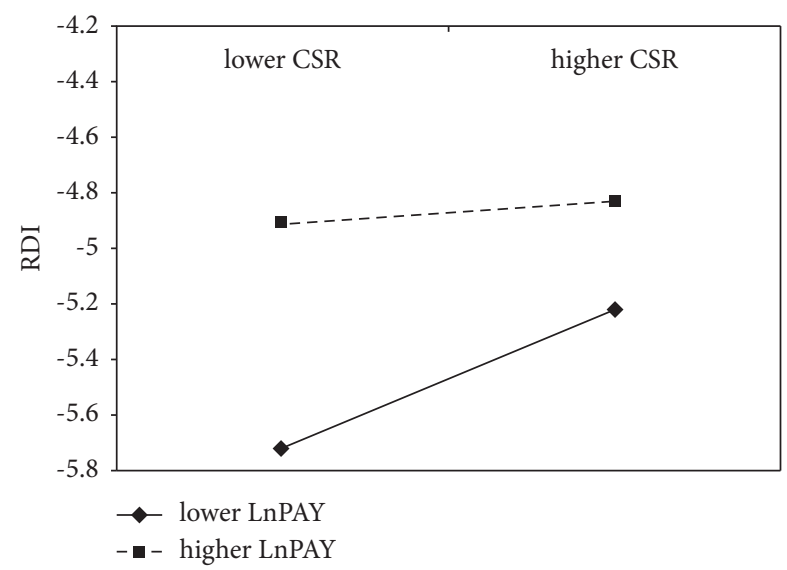

FIGURE 2: The moderating effect of executive compensation incentive on CSR performance and innovation investment of private enterprises

two paths: obtaining government subsidies and improving market position to enhance external competitive advantage. From Panel (1) of the table, it can be seen that enterprises can
TABLe 7: Path analysis.

\begin{tabular}{|c|c|c|c|c|}
\hline \multirow[t]{2}{*}{ VARIABLES } & \multicolumn{2}{|c|}{$\begin{array}{l}\text { (1) Path test of } \\
\text { government resource } \\
\text { exchange }\end{array}$} & \multicolumn{2}{|c|}{$\begin{array}{l}\text { (2) Path test of market } \\
\text { dominance }\end{array}$} \\
\hline & LnGOV & RDI & $\mathrm{Pcm}$ & RDI \\
\hline$\overline{C S R}$ & $\begin{array}{c}0.080^{* * *} \\
(5.15)\end{array}$ & $\begin{array}{c}0.049^{* *} \\
(2.36)\end{array}$ & $\begin{array}{c}0.120^{* * *} \\
(11.40)\end{array}$ & $\begin{array}{c}0.055^{* * *} \\
(2.58)\end{array}$ \\
\hline LnGOV & & $\begin{array}{c}0.251^{* * *} \\
(10.79)\end{array}$ & & \\
\hline $\mathrm{Pcm}$ & & & & $\begin{array}{c}0.046^{* *} \\
(2.18)\end{array}$ \\
\hline AGE & $\begin{array}{c}-0.040^{* * *} \\
(-10.16)\end{array}$ & $\begin{array}{c}-0.017^{* * *} \\
(-3.94)\end{array}$ & $\begin{array}{l}-0.003 \\
(-1.36)\end{array}$ & $\begin{array}{c}-0.022^{* * *} \\
(-4.93)\end{array}$ \\
\hline $\operatorname{Ln} A$ & $\begin{array}{c}-0.114^{* * *} \\
(-6.37)\end{array}$ & $\begin{array}{c}0.860^{* * *} \\
(36.86)\end{array}$ & $\begin{array}{l}-0.020 \\
(-1.34)\end{array}$ & $\begin{array}{c}0.823^{* * *} \\
(34.01)\end{array}$ \\
\hline $\mathrm{BOA}$ & $\begin{array}{l}-0.002 \\
(-0.20)\end{array}$ & $\begin{array}{l}-0.006 \\
(-0.47)\end{array}$ & $\begin{array}{l}-0.002 \\
(-0.39)\end{array}$ & $\begin{array}{l}-0.003 \\
(-0.24)\end{array}$ \\
\hline Share1 & $\begin{array}{l}-0.001 \\
(-0.58)\end{array}$ & $\begin{array}{l}-0.001 \\
(-0.66)\end{array}$ & $\begin{array}{c}0.009^{* * *} \\
(8.43)\end{array}$ & $\begin{array}{l}-0.003 \\
(-1.42)\end{array}$ \\
\hline Balance & $\begin{array}{l}-0.013 \\
(-0.40)\end{array}$ & $\begin{array}{l}-0.009 \\
(-0.21)\end{array}$ & $\begin{array}{c}0.115^{* * *} \\
(6.32)\end{array}$ & $\begin{array}{l}-0.028 \\
(-0.62)\end{array}$ \\
\hline TobinsQ & $\begin{array}{l}0.005 \\
(0.67)\end{array}$ & $\begin{array}{c}0.095^{* * *} \\
(5.49)\end{array}$ & $\begin{array}{l}-0.004 \\
(-0.24)\end{array}$ & $\begin{array}{c}0.088^{* * *} \\
(5.34)\end{array}$ \\
\hline ROE & $\begin{array}{l}0.301 \\
(1.61)\end{array}$ & $\begin{array}{c}0.757^{* *} \\
(2.09)\end{array}$ & $\begin{array}{l}1.275^{* * *} \\
(3.54)\end{array}$ & $\begin{array}{l}0.610^{*} \\
(1.87)\end{array}$ \\
\hline Irr & $\begin{array}{c}0.000^{* * *} \\
(3.02)\end{array}$ & $\begin{array}{c}-0.002^{* * *} \\
(-14.01)\end{array}$ & $\begin{array}{l}0.000 \\
(0.99)\end{array}$ & $\begin{array}{c}-0.002^{* * *} \\
(-12.52)\end{array}$ \\
\hline $\mathrm{CF}$ & $\begin{array}{c}1.090^{* * *} \\
(4.24)\end{array}$ & $\begin{array}{c}0.667^{*} \\
(1.70)\end{array}$ & $\begin{array}{c}1.070^{* * *} \\
(5.73)\end{array}$ & $\begin{array}{c}0.853^{* *} \\
(2.18)\end{array}$ \\
\hline YEAR & control & control & control & control \\
\hline IND & control & control & control & control \\
\hline PROV & control & control & control & control \\
\hline Constant & $\begin{array}{c}-2.842^{* * *} \\
(-7.04)\end{array}$ & $\begin{array}{c}-2.275^{* * *} \\
(-3.53)\end{array}$ & $\begin{array}{c}-2.482^{* * *} \\
(-7.43)\end{array}$ & $\begin{array}{c}-2.495^{* * *} \\
(-3.80)\end{array}$ \\
\hline Observations & 5,662 & 3,457 & 5,644 & 3,354 \\
\hline R-squared & 0.235 & 0.473 & 0.250 & 0.449 \\
\hline F test & 0 & 0 & 0 & 0 \\
\hline Adj_R2 & 0.230 & 0.467 & 0.245 & 0.443 \\
\hline $\mathrm{F}$ & 39.09 & 88.97 & 43.58 & 72.62 \\
\hline
\end{tabular}

obtain more government subsidies by performing CSR, and the government subsidies promote the increase of enterprises' innovation investment. This is because private enterprises in China still face the problem of financing constraints in their development [40], and enterprises obtain compensation for resources by catering to the government's needs and sharing part of the government's public responsibilities in order to achieve resource exchange. And the increased government subsidies can better solve the input problem of innovation projects. The results of Panel (2) show that CSR activities of firms are conducive to increasing market dominance, and the increase in market dominance is also conducive to the increase in firms' innovation investment. Enterprises improve social recognition through CSR performance, form external competitive advantages, and win discourse and influence in the industry, and this favorable market position will regulate the supply of production factors, which drives the increase of enterprise innovation investment. The empirical results show that both paths pass the test. 
(4) Combining the dynamic considerations of different life cycles of enterprises. The results of the empirical analysis combining different life cycles of the enterprises are shown in Table 8, from which it can be seen that.

(1) CSR performance is always effective in promoting enterprises to make more innovation investment only when they are in the maturity stage. This may be due to the fact that enterprises in the growth phase stage have not formed a perfect CSR fulfillment system on the one hand, and the market competition is fierce on the other hand, and the profit margin available is very low, so it is difficult for enterprises to continuously load various CSR expenditures, and they have to apply conservative decisions and weaken CSR performance. In the recessionary stage, the company is already unable to make ends meet, and at this time executives are not very motivated to carry out innovative activities, so none of them can fully function. In contrast, companies in the maturity stage have a good development trend, and as they gain more profits, they have enough cash flow and energy internally to actively practice CSR activities in order to strengthen their ties with the public, which will further enhance the positive image of the company and its external competitive advantage, and obtain more tangible and intangible resources for future development, so they can promote the increase of innovation investment, and the hypothesis $\mathrm{H} 3 \mathrm{a}$ is verified.

(2) Executive compensation incentives positively promote innovation investment regardless of whether the firm is in the growth, maturity, or recession stage. This may be because the existence of an incentive system makes management have a strong belief in the firm's growth and helps to direct management's attention to less prominent but financially important investment activities for the firm in the long run, thus enhancing innovation investment.

(3) Executive compensation incentives weaken the catalytic effect of CSR performance on innovation investment during maturity and recession. Hypothesis $\mathrm{H} 3 \mathrm{~b}$ is verified. The reason for this is that during the business growth period, the internal resources of the company are relatively tight and there is not a perfect CSR fulfillment and incentive policy, while in the maturity stage, the company gradually forms a perfect corporate governance system, but with the significant increase in management compensation, the executives gradually reduce the spirit of innovation and begin to appear short-sighted and selfinterested behavior, and this negative behavior leads to the relationship between CSR performance and innovation investment on Weakening effect. Entering the recession period, the decline of organizational performance will further enhance the self-interest behavior of executives, thus having the same weakening effect.
(4) The path test of government resource exchange shows that only firms in the maturity stage can realize the resource exchange effect of CSR performance and enhance innovation investment by obtaining government subsidies. Hypothesis $\mathrm{H} 3 \mathrm{c}$ is verified. It is also found that although CSR performance cannot promote the enhancement of innovation investment due to their own strengths, there is a significant positive effect on government subsidies, indicating that mature stage firms can still obtain government attention through fulfilling CSR activities, which is beneficial to their development in a benign way. Entering the recession period, it is difficult for firms to realize the exchange of resources with the government.

(5) The path test of market dominance shows that CSR performance by firms in the maturity stage can enhance innovation investment through market status. Hypothesis H3d is verified. CSR performance by firms in the maturity stage can help firms initially establish a market dominance position, but it does not effectively translate into a substantial increase in innovation investment. Surprisingly, this path still holds for firms in the decline stage. This indicates that although the performance of firms in recession is declining, they actually face various opportunities for change, which require a strong innovative spirit among entrepreneurs. By maintaining a sense of responsibility, the situation can still be turned around through good CSR behavior. This also confirms, to some extent, the research of $\mathrm{Li}$, Sihai, and other related scholars [20], that declining companies do not reduce social giving because of the decline in profitability, and "strategic philanthropy" can still play a certain strategic utility.

(5) Robustness tests. In order to enhance the validity of the research results, this paper mainly uses three methods to conduct robustness tests, and the results are shown in Table 9 and Table 10. first, existing scholarly research finds that corporate CSR fulfillment has an impact on innovation inputs, but corporate innovation may also in turn affect corporate CSR activities. Thus, this paper draws on the research methods of Leilei Gu and Wenjing Ouyang [41] and Shouming Chen and Jie Zhou [42] to conduct robustness tests using one-period lags (L1.CSR) and two-period lags (L2.CSR) of CSR indicators, and this treatment helps to mitigate possible endogeneity problems and forward-looking bias. At the same time, the measures of innovation input and executive compensation incentive were changed based on related studies $[10,36]$. The natural logarithm of $R \& D$ investment $(\operatorname{LnRD})$ is used as a proxy variable for the innovation investment indicator, and the natural logarithm of total compensation of the top three executives is used as a proxy variable for the executive compensation incentive indicator. The related results are shown in Table 9. from the results in the table, it is clear that L1.CSR and L2. CSR term 


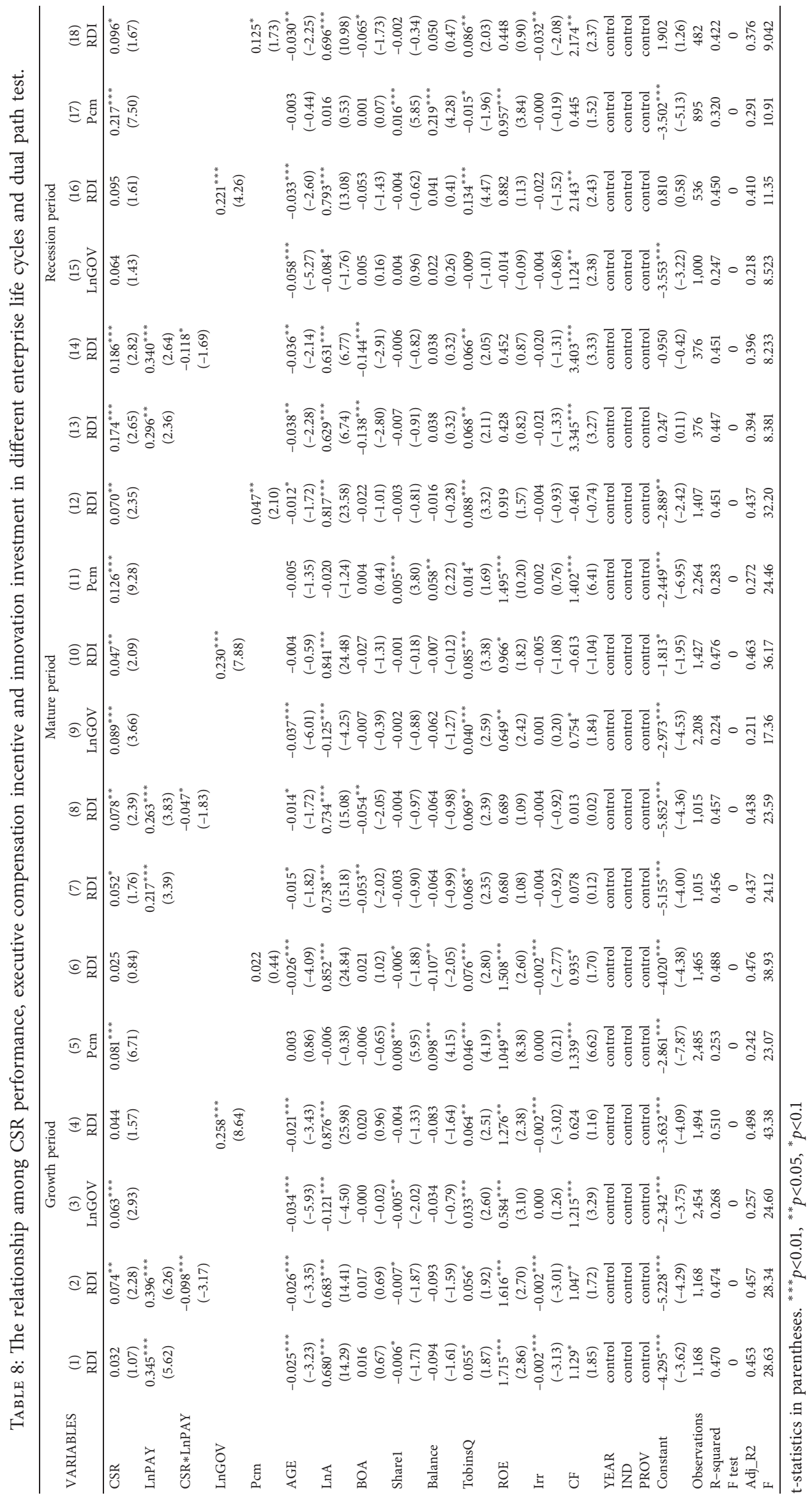


TABLE 9: Robustness test: consider the time lag effect and change the measurement method of innovation investment.

\begin{tabular}{|c|c|c|c|c|c|c|}
\hline VARIABLES & $\begin{array}{c}(1) \\
\text { LnRD }\end{array}$ & $\begin{array}{c}(3) \\
\text { LnRD }\end{array}$ & $\begin{array}{c}(5) \\
\operatorname{LnRD}\end{array}$ & $\begin{array}{c}(2) \\
\operatorname{LnRD}\end{array}$ & $\begin{array}{c}(4) \\
\text { LnRD }\end{array}$ & $\begin{array}{c}(6) \\
\operatorname{LnRD}\end{array}$ \\
\hline L1.CSR & $\begin{array}{c}0.077^{* * *} \\
(3.91)\end{array}$ & $\begin{array}{c}0.062^{* * *} \\
(3.01)\end{array}$ & $\begin{array}{c}0.094^{* * *} \\
(3.84)\end{array}$ & & & \\
\hline L2.CSR & & & & $\begin{array}{c}0.091^{* * *} \\
(4.78)\end{array}$ & $\begin{array}{c}0.076^{* * *} \\
(3.75)\end{array}$ & $\begin{array}{c}0.103^{* * *} \\
(4.24)\end{array}$ \\
\hline LnPAY_3 & & $\begin{array}{c}0.253^{* * *} \\
(4.57)\end{array}$ & $\begin{array}{c}0.301^{* * *} \\
(5.27)\end{array}$ & & $\begin{array}{c}0.231^{* * *} \\
(3.87)\end{array}$ & $\begin{array}{c}0.279^{* * *} \\
(4.53)\end{array}$ \\
\hline L1CSR $*$ LnPAY_3 & & & $\begin{array}{c}-0.059^{* * *} \\
(-2.69)\end{array}$ & & & \\
\hline L2CSR $*$ LnPAY_3 & & & & & & $\begin{array}{c}-0.049^{* *} \\
(-2.17)\end{array}$ \\
\hline AGE & $\begin{array}{c}-0.022^{* * *} \\
(-4.08)\end{array}$ & $\begin{array}{c}-0.023^{* * *} \\
(-3.37)\end{array}$ & $\begin{array}{c}-0.022^{* * *} \\
(-3.25)\end{array}$ & $\begin{array}{c}-0.032^{* * *} \\
(-4.53)\end{array}$ & $\begin{array}{c}-0.031^{* * *} \\
(-3.60)\end{array}$ & $\begin{array}{c}-0.030^{* * *} \\
(-3.51)\end{array}$ \\
\hline $\operatorname{Ln} A$ & $\begin{array}{c}0.789^{* * *} \\
(26.63)\end{array}$ & $\begin{array}{c}0.693^{* * *} \\
(16.33)\end{array}$ & $\begin{array}{c}0.692^{* * *} \\
(16.44)\end{array}$ & $\begin{array}{c}0.801^{* * *} \\
(22.90)\end{array}$ & $\begin{array}{c}0.700^{* * *} \\
(14.18)\end{array}$ & $\begin{array}{c}0.699^{* * *} \\
(14.19)\end{array}$ \\
\hline $\mathrm{BOA}$ & $\begin{array}{l}-0.006 \\
(-0.32)\end{array}$ & $\begin{array}{l}-0.024 \\
(-1.17)\end{array}$ & $\begin{array}{l}-0.023 \\
(-1.15)\end{array}$ & $\begin{array}{l}-0.015 \\
(-0.77)\end{array}$ & $\begin{array}{l}-0.028 \\
(-1.23)\end{array}$ & $\begin{array}{l}-0.029 \\
(-1.24)\end{array}$ \\
\hline Share 1 & $\begin{array}{c}-0.005^{*} \\
(-1.66)\end{array}$ & $\begin{array}{l}-0.005 \\
(-1.50)\end{array}$ & $\begin{array}{l}-0.005 \\
(-1.56)\end{array}$ & $\begin{array}{c}-0.008^{* * *} \\
(-2.62)\end{array}$ & $\begin{array}{c}-0.007^{* *} \\
(-2.02)\end{array}$ & $\begin{array}{c}-0.007^{* *} \\
(-2.04)\end{array}$ \\
\hline Balance & $\begin{array}{l}-0.037 \\
(-0.67)\end{array}$ & $\begin{array}{l}-0.066 \\
(-0.99)\end{array}$ & $\begin{array}{l}-0.061 \\
(-0.92)\end{array}$ & $\begin{array}{l}-0.078 \\
(-1.21)\end{array}$ & $\begin{array}{l}-0.070 \\
(-0.90)\end{array}$ & $\begin{array}{l}-0.065 \\
(-0.82)\end{array}$ \\
\hline TobinsQ & $\begin{array}{c}0.082^{* * *} \\
(4.09)\end{array}$ & $\begin{array}{c}0.070^{* * *} \\
(3.06)\end{array}$ & $\begin{array}{c}0.072^{* * *} \\
(3.15)\end{array}$ & $\begin{array}{c}0.084^{* * *} \\
(3.76)\end{array}$ & $\begin{array}{c}0.071^{* * *} \\
(2.84)\end{array}$ & $\begin{array}{c}0.073^{* * *} \\
(2.90)\end{array}$ \\
\hline $\mathrm{ROE}$ & $\begin{array}{c}1.140^{* * *} \\
(2.64)\end{array}$ & $\begin{array}{c}0.929^{*} \\
(1.89)\end{array}$ & $\begin{array}{c}0.936^{*} \\
(1.90)\end{array}$ & $\begin{array}{c}1.072^{* * *} \\
(2.67)\end{array}$ & $\begin{array}{c}0.765^{* *} \\
(2.08)\end{array}$ & $\begin{array}{c}0.745^{* *} \\
(2.05)\end{array}$ \\
\hline Irr & $\begin{array}{c}-0.002^{*} \\
(-1.66)\end{array}$ & $\begin{array}{c}-0.003^{*} \\
(-1.75)\end{array}$ & $\begin{array}{c}-0.003^{* *} \\
(-2.02)\end{array}$ & $\begin{array}{l}-0.002 \\
(-0.82)\end{array}$ & $\begin{array}{l}-0.002 \\
(-0.83)\end{array}$ & $\begin{array}{l}-0.002 \\
(-0.83)\end{array}$ \\
\hline $\mathrm{CF}$ & $\begin{array}{c}1.153^{* *} \\
(2.52)\end{array}$ & $\begin{array}{c}1.289^{* *} \\
(2.46)\end{array}$ & $\begin{array}{c}1.206^{* *} \\
(2.31)\end{array}$ & $\begin{array}{c}1.489^{* * * *} \\
(2.86)\end{array}$ & $\begin{array}{c}1.549^{* * *} \\
(2.75)\end{array}$ & $\begin{array}{c}1.466^{* * *} \\
(2.62)\end{array}$ \\
\hline YEAR & control & control & control & control & control & control \\
\hline IND & control & control & control & control & control & control \\
\hline PROV & control & control & control & control & control & control \\
\hline Constant & $\begin{array}{c}-2.759^{* * *} \\
(-3.59)\end{array}$ & $\begin{array}{c}-4.139^{* * *} \\
(-4.30)\end{array}$ & $\begin{array}{c}-4.974^{* * *} \\
(-4.98)\end{array}$ & $\begin{array}{c}-1.629^{*} \\
(-1.89)\end{array}$ & $\begin{array}{c}-3.596^{* * *} \\
(-3.42)\end{array}$ & $\begin{array}{c}-4.374^{* * *} \\
(-4.01)\end{array}$ \\
\hline Observations & 2,555 & 1,984 & 1,984 & 2,158 & 1,707 & 1,707 \\
\hline R-squared & 0.438 & 0.430 & 0.433 & 0.441 & 0.435 & 0.437 \\
\hline $\mathrm{F}$ test & 0 & 0 & 0 & 0 & & \\
\hline Adj_R2 & 0.431 & 0.420 & 0.422 & 0.432 & 0.423 & 0.425 \\
\hline $\mathrm{F}$ & 52.41 & 42.02 & 41.84 & 72.37 & . & . \\
\hline
\end{tabular}

Robust t-statistics in parentheses. ${ }^{* * *} p<0.01,{ }^{* *} p<0.05,{ }^{*} p<0.1$

always has a significant positive relationship with the innovation investment $L n R D$ term, indicating that CSR activities performed by firms are conducive to enhancing subsequent innovation investment efforts with long-term and persistence. In the interaction term between executive compensation incentives and L1.CSR and L2.CSR, the sign remains unchanged and the negative moderating effect remains significant. It indicates that the results remain stable after accounting for the time lag effect. The test results still support $\mathrm{H} 2 \mathrm{a}$ and $\mathrm{H} 2 \mathrm{~b}$.

Finally, both corporate CSR behavior and innovation investment are an allocation of corporate resources to operations. CSR fulfillment affects innovation investment, and corporate innovation investment may, in turn, affect CSR fulfillment. And certain control variables are inevitably missed when considering the role of CSR fulfillment in influencing firms' innovation inputs. Therefore, this paper uses a two-stage instrumental variables approach (IV-2SLS) to detect possible endogeneity problems. The instrumental variable for CSR fulfillment is selected as the industry average CSR level (IV.CSR) of private firms for each year. Theoretically, the industry average CSR of private enterprises by year is significantly correlated with corporate CSR and will not be correlated with corporate $R \& D$ investment, so it is suitable as an instrumental variable. The results of the second stage in Table 10 show that there is still a positive relationship between CSR fulfillment and corporate innovation investment, and it passes the $1 \%$ significance level test. It indicates that the results remain stable after considering the endogeneity issue. 
TABLe 10: Robustness test: two-stage least squares method.

\begin{tabular}{|c|c|c|}
\hline VARIABLES & $\begin{array}{l}\text { (1) } \\
\text { first stage } \\
\text { CSR }\end{array}$ & $\begin{array}{c}(2) \\
\text { second stage } \\
R D I\end{array}$ \\
\hline IV.CSR & $\begin{array}{c}0.1172^{* * *} \\
(0.005)\end{array}$ & \\
\hline CSR & & $\begin{array}{c}1.2591^{* * *} \\
(0.167)\end{array}$ \\
\hline$A G E$ & $\begin{array}{c}-0.0084^{* *} \\
(0.004)\end{array}$ & $\begin{array}{c}-0.0813^{* * *} \\
(0.014)\end{array}$ \\
\hline $\operatorname{Ln} A$ & $\begin{array}{c}0.1864^{* * *} \\
(0.018)\end{array}$ & $\begin{array}{c}0.2035^{* * *} \\
(0.074)\end{array}$ \\
\hline$B O A$ & $\begin{array}{l}0.0002 \\
(0.012)\end{array}$ & $\begin{array}{c}0.0102 \\
(0.044)\end{array}$ \\
\hline Share1 & $\begin{array}{c}0.0042^{* *} \\
(0.002)\end{array}$ & $\begin{array}{c}-0.0236^{* * *} \\
(0.007)\end{array}$ \\
\hline Balance & $\begin{array}{l}0.0347 \\
(0.031)\end{array}$ & $\begin{array}{l}0.0910 \\
(0.111)\end{array}$ \\
\hline TobinsQ & $\begin{array}{l}0.0033 \\
(0.012)\end{array}$ & $\begin{array}{c}0.6889^{* * *} \\
(0.044)\end{array}$ \\
\hline$R O E$ & $\begin{array}{c}3.2809^{* * *} \\
(0.246)\end{array}$ & $\begin{array}{c}-0.7127 \\
(1.080)\end{array}$ \\
\hline Irr & $\begin{array}{c}-0.0004 \\
(0.001)\end{array}$ & $\begin{array}{c}-0.0016 \\
(0.002)\end{array}$ \\
\hline$C F$ & $\begin{array}{c}2.2736^{* * *} \\
(0.291)\end{array}$ & $\begin{array}{c}-0.4161 \\
(1.102)\end{array}$ \\
\hline$Y E A R$ & control & control \\
\hline IND & control & control \\
\hline PROV & control & control \\
\hline Constant & $\begin{array}{c}-4.9835^{* * *} \\
(0.426)\end{array}$ & $\begin{array}{l}2.6455 \\
(1.519)\end{array}$ \\
\hline Observations & 3,486 & 3,486 \\
\hline R-squared & 0.303 & 0.317 \\
\hline
\end{tabular}

Robust t-statistics in parentheses. ${ }^{* * *} p<0.01,{ }^{* *} p<0.05,{ }^{*} p<0.1$

\section{Conclusion and Implications}

5.1. Research Conclusion. By introducing social exchange theory, signaling theory, and enterprise life cycle theory, this paper focuses on private enterprises, starts from the main line that CSR behavior affects enterprise innovation investment, elaborates the resource exchange role and signaling motive of enterprise CSR behavior, empirically analyzes the relationship between CSR performance, executive compensation incentives and innovation investment, and examines the role of government and market in it. Finally, it is organically combined with the weighted factor of the firm's life cycle to empirically analyze how this mechanism of action varies with the life stage of the firm. The results show that:(1) CSR activities are conducive to enhancing innovation investment; (2) executive compensation incentives have a negative moderating effect on the relationship between CSR performance and innovation investment in mature and declining stage companies; (3) CSR performance can only be enhanced by obtaining more government subsidies and realizing the exchange effect of government resources to enhance innovation investment in mature and declining stage companies; (4) CSR performance can only be enhanced by obtaining more government subsidies in mature and declining stage companies; (5) CSR performance can only be enhanced by obtaining more government subsidies to enhance innovation investment in mature and declining stage companies. (4) In both maturity and recession stages, CSR fulfillment can enhance innovation investment by obtaining external competitive advantage and achieving market dominance.

5.2. Management Implications. This study has theoretical and practical implications for the implementation of CSR programs in private enterprises in China. At the theoretical level, the existing literature on the relationship between CSR fulfillment, executive compensation incentives and innovation investment based on the dynamic perspective of corporate life cycle is relatively scarce, and this paper's dynamic examination from the perspective of different life stages is a useful addition to the research related to private enterprises' fulfillment of responsibilities and innovation investment. Secondly, social responsibility, as a factor that must be taken into account when a company enters into a contract with society, acts like innovation strategy in the whole process of corporate growth. Both CSR fulfillment and innovation $\mathrm{R} \& \mathrm{D}$ require long-term large-scale investment of resources by enterprises, but there is a lack of in-depth research on the corresponding paths. This paper explores the resource acquisition mechanism behind the concurrent focus of CSR fulfillment and innovation investment in private enterprises from the perspective of social exchange, verifying that CSR behavior can improve access to social tangible and intangible resources indirectly acting on corporate innovation investment, providing further support for the strategic motivation of CSR behavior. From a practical point of view, a company is a dynamic functional organization system, and managers have to consider various factors in different periods of time to implement strategies. Lack of CSR implementation can expose companies to huge business risks such as environmental damage and talent loss, while lack of incentive-driven innovation investment can seem overwhelming. Companies that do not adapt their strategies to their current life cycle are likely to do the opposite. Therefore, this paper explains from a dynamic perspective when corporate innovation investment is influenced by CSR fulfillment and executive compensation incentives, and what are the paths of influence at different stages, in order to guide enterprises to give full play to the different paths of conduction according to their own realistic stage, and to integrate the three organically, which can help optimize industrial structure, break through the existing "neck" technology bottleneck, and achieve value. It is of practical significance to optimize the industrial structure, break through the existing "neck" technology bottleneck, realize the value chain to the high-end climb, and stimulate the innovation vitality of the whole society.

This paper makes the following recommendations for current private firms:

(1) Overall, CSR activities are a favorable strategy for private firms to innovate. The results of this paper show that CSR fulfillment is conducive to enhancing enterprise innovation investment, and CSR behavior has good political effect and strategic function, which 
can promote the increase of innovation investment through government resource exchange effect and market dominant position ingestion. This undoubtedly points to a new direction of choice for the long-term strategic development of private enterprises in China. The Opinions of the State Council of the CPC Central Committee on Creating a Healthy Growth Environment for Entrepreneurs to Promote Excellent Entrepreneurship and Better Play the Role of Entrepreneurs, published in September 2017, also proposes to promote the spirit of entrepreneurs to fulfill their responsibilities and dare to serve the society. Therefore, the future development of private enterprises needs to deepen the understanding of CSR behavior, adapt CSR projects to the needs of local governments, and achieve real relief for the people and give back to society in order to obtain more advanced production factors while fulfilling CSR, realize the resource exchange effect, enhance their advantageous market position, and play an enhancing role in innovation investment.

(2) The executive compensation incentive system in private firms is conducive to promoting innovation activities, but it weakens the role of CSR fulfillment in enhancing innovation investment. This may be due to the fact that excessive pay incentives tend to lead to the accumulation of executive inertia and loss of motivation, and the fear that the favorable position at this time will be affected reluctance to increase CSR spending. Therefore, companies should avoid the misconception that high pay is all that matters when making incentive model choices, and aggressive pay incentives are not the first choice for private companies in China. In addition, the role of executive compensation incentives on the relationship between CSR fulfillment and innovation investment varies according to the life cycle of enterprises. Enterprises should fully examine the actual internal and external conditions, design differentiated executive incentive mechanisms, such as specific CSR fulfillment targets, challenging innovation indicators, and dynamically adjust the incentive methods in line with the development stage and internal and external contexts of enterprises in order to fully stimulate entrepreneurship and help enterprises become ethical to achieve a win-win situation for all. At the same time, the board of directors' inspection obligation should be enhanced to reduce the hidden self-interest of executives for opportunistic motives.

(3) Promoting CSR performance of private enterprises is never only an internal matter of enterprises, but also requires the joint efforts of the government and society to create a resource environment and social atmosphere that respects and encourages entrepreneurs to develop a sense of responsibility and innovation, so as to activate the endogenous motivation of private enterprises to perform CSR. Moreover, local governments should consider the heterogeneity of enterprise life cycles when formulating financial incentive policies, implement differentiated and precise policy formulation and management, and maximize the synergy between the "reciprocal measures" of government subsidies and enterprise development stages, so that the strategic guidance function of financial resources can be put into practice and help enterprises move from creating economic value to creating shared value.

5.3. Research Limitations and Future Prospects. First, this paper is limited to the study of data from private listed companies in China, and the analysis findings may have some limitations. The existence of a large number of nonlisted companies and their managers' lack of public control may have a greater impact on corporate innovation investment, while the CSR behaviors and goals of private and state-owned enterprises are different, and the effects of management compensation incentives also differ greatly. In the future, the research context can be expanded to explore the differences in CSR behaviors under different corporate characteristics, cultures and market environments, and at the same time, not only innovation input, but also innovation output and transformation capacity should be considered. We should also consider not only innovation input but also innovation output and transformation ability. Second, according to Bohlmann et al [43], CSR consists of three dimensions: economic, social, and environmental. The decomposition of different dimensions of CSR behaviors can be brought in the future. In addition, does the heterogeneity of government subsidy resources, such as different levels of subsidies, the amount of variation in subsidies, the specific content and limited constraints of subsidies, etc., produce different utility? Future research can pay further attention to this.

\section{Data Availability}

The data used to support the findings of this study are included within the article.

\section{Conflicts of Interest}

The authors declare that there is no conflict of interest regarding the publication of this paper.

\section{References}

[1] H. Xiao and Z. Yang, "The evolution of business-society relations in 70 years of new China: process, logic and prospects[J]," Reformation, no. 6, pp. 5-19, 2019.

[2] Z. G. Zhang, Y. J. Li, and L. Li, "Research on the relationship between corporate charitable giving, access to science and technology resources and innovation performance-based on the perspective of resource exchange between companies and government[J]," Nankai Management Review, vol. 19, no. 3, pp. 123-135, 2016.

[3] Y. Ueki, C. Jeenanunta, T. Machikita, and M. Tsuji, "Does safety-oriented corporate social responsibility promote 
innovation in the Thai trucking industry?" Journal of Business Research, vol. 69, no. 11, pp. 5371-5376, 2016.

[4] E. Bacinello, G. Tontini, and A. Alberton, "Influence of maturity on corporate social responsibility and sustainable innovation in business performance," Corporate Social Responsibility and Environmental Management, vol. 27, no. 2, pp. 749-759, 2020.

[5] A. Kamidi and J. Guo, "Corporate social responsibility and innovation: the moderating role of executive team tenure and its heterogeneity [J]," China Science and Technology Forum, no. 3, pp. 133-142+180, 2021.

[6] D. H. M. Chng, E. Shih, M. S. Rodgers, and X.-B. Song, "Managers' marketing strategy decision making during performance decline and the moderating influence of incentive pay," Journal of the Academy of Marketing Science, vol. 43, no. 5, pp. 629-647, 2015.

[7] D. Chen and L. Xing, "Social donation, executive incentives and private firms' R\&D investment[J]," Industrial Economics Research, no. 6, pp. 76-88, 2019.

[8] J. Chen and Z. Wen, "Family control, executive incentives and corporate social responsibility--an empirical study based on Chinese family listed companies[J]," Journal of Nanjing Audit University, vol. 14, no. 3, pp. 66-74, 2017.

[9] A. J. Hillman and G. D. Keim, "Shareholder value, stakeholder management, and social issues: what's the bottom line?" Strategic Management Journal, vol. 22, no. 2, pp. 125-139, 2001.

[10] S. Gholami, "Value creation model through corporate social responsibility (CSR)[J]," International Journal of Business and Management, vol. 6, no. 9, 2011.

[11] M. Shi, X. Cai, and X. Geng, "Corporate social responsibility, $\mathrm{R} \& \mathrm{D}$ investment and debt financing cost under dynamic environment-an empirical study based on private listed companies in Chinese manufacturing industry[J]," Journal of Shanxi University of Finance and Economics, vol. 39, no. 3, pp. 111-124, 2017.

[12] J. Surroca, J. A. Tribó, and S. Waddock, "Corporate responsibility and financial performance: the role of intangible resources," Strategic Management Journal, vol. 31, no. 5, pp. 463-490, 2010.

[13] Sihai, Li, Xianzhong et al., "Political connection, ownership structure, and corporate philanthropy in China: a strategicpolitical perspective[J]," Journal of Business Ethics, vol. 129, no. 2, pp. 399-411, 2015.

[14] M. Zhang, L. Ma, and W. Zhang, "The government-enterprise bonding effect of corporate charitable giving--empirical evidence based on listed companies in China [J]," Management World, no. 7, pp. 163-171, 2013.

[15] W.'an Li, P. Wang, and Y. Xu, "Charitable giving, political affiliation and debt financing--resource exchange behavior of private firms and government[J]," Nankai Management Review, vol. 18, no. 1, pp. 4-14, 2015.

[16] Z. Li, X. Tang, and Y. Lian, "The mystery of Chinese private enterprises' social responsibility deviation," Management World, no. 9, pp. 136-148+160+188, 2016.

[17] L. G. Sergio, "Strategizing by the government: can industrial policy create firm-level competitive advantage," Strategic Management Journal, vol. 36, no. 1, pp. 97-112, 2015.

[18] C. Dong and L. Xing, "Do government subsidies enhance the scale and quality of enterprises' investment--a perspective based on the comparison of state-owned enterprises and private enterprises [J]," Journal of Shanxi University of Finance and Economics, vol. 41, no. 8, pp. 84-99, 2019.

[19] S. Li, X. Chen, and X. Song, "Generosity of the poor:A study of strategic motivation," Management World, no. 5, pp. 116-127+140, 2016.
[20] J. Hu, H. Wang, and X. Song, "Do corporate charitable donations have strategic effects? --Based on the perspective of product market competition[J]," Audit and Economic Research, vol. 32, no. 4, pp. 83-92, 2017.

[21] A. Mcwilliams, D. S. Siegel, and P. M. Wright, "Corporate social responsibility: strategic implications*," Journal of Management Studies, vol. 43, no. 1, pp. 1-18, 2006.

[22] X. Wang, J. Meng, and X. Chen, "Brand meaning reinvention process under the CSR perspective--a case study based on Dong Ah Giao [J]," Management Review, vol. 33, no. 2, pp. 323-337, 2021.

[23] F. Liu, J. Li, and L. Yang, "Research on the relationship between corporate social responsibility, moral identity and employees' organizational citizenship behavior[J]," China Soft Science, no. 6, pp. 117-129, 2017.

[24] Y. Tang, J. Zuo, and H. Li, "Research on the mechanism of the influence of institutional environment changes on corporate philanthropic behavior [J]," Economic Research, vol. 49, no. 2, pp. 61-73, 2014.

[25] M. Bai and R. Wang, "How corporate social responsibility affects sustainable corporate innovation," China Science and Technology Forum, no. 1, pp. 107-115, 2020.

[26] R. K. Aggarwal and A. A. Samwick, "Empire-builders and shirkers: investment, firm performance, and managerial incentives," Journal of Corporate Finance, vol. 12, no. 3, pp. 489-515, 2006.

[27] F. Gu, L. Zhang, and F. Zhang, "Life cycle, executive compensation incentives and corporate innovation investmentempirical evidence from GEM listed companies[J]," Journal of Zhongnan University of Economics and Law, no. 1, pp. 146156, 2018.

[28] L. A. Bebchuk and J. M. Fried, "Executive compensation as an agency problem," The Journal of Economic Perspectives, vol. 17, no. 3, pp. 71-92, 2003.

[29] Y. Li, Li Zhan, and S. Tang, "Corporate life cycle, corporate governance and efficiency of corporate capital allocation[J]," Nankai Management Review, vol. 14, no. 03, pp. 110-121, 2011.

[30] I. Adizes, How and Why Corporation Grow and Die and what to Do about it: Corporate Life Cycle, Prentice-Hall, Englewood Cliffs, NJ, 1989.

[31] M. P. Narayanan, "Managerial incentives for short-term results," The Journal of Finance, vol. 40, no. 5, pp. 1469-1484, 1985.

[32] M. C. Jensen and W. H. Meckling, Theory of the Firm: Managerial Behavior, Agency Costs, and Ownership Structure [M], Springer Netherlands, 1979.

[33] M. Bertrand and S. Mullainathan, "Enjoying the quiet life? Corporate governance and managerial preferences," Journal of Political Economy, vol. 111, no. 5, pp. 1043-1075, 2003.

[34] R. Y. Ji, J. Yu, and H. P. Ruan, "Research on the impact of firm size and R\&D investment on innovation performance based on credit environment and knowledge stock perspective [J]," East China Economic Management, vol. 34, no. 09, pp. 43-54, 2020.

[35] Z. Wang and Baisheng, "Corporate social responsibility, innovation capability and internationalization strategy - the moderating role of executive compensation incentives [J]," Management Review, vol. 31, no. 03, pp. 193-202, 2019.

[36] J. Peress, "Product market competition, insider trading, and stock market efficiency," The Journal of Finance, vol. 65, no. 1, pp. 1-43, 2010.

[37] V. Dickinson, "Cash flow patterns as a proxy for firm life cycle," The Accounting Review, vol. 86, no. 6, pp. 1969-1994, 2011. 
[38] P. Xie and C. Wang, "Management power, corporate life cycle and investment efficiency-an empirical study based on Chinese listed manufacturing companies [J]," Nankai Management Review, vol. 20, no. 01, pp. 57-66, 2017.

[39] C. Dong, "Funders' background, speculative investment and corporate performance in private firms [J]," Management World, no. 8, pp. 97-119+187-188, 2015.

[40] X. H. Gong and Q. Ren, "Financing constraints, credit support and foreign direct investment of private enterprises[J]," Industrial Economics Research, no. 5, pp. 25-37, 2017.

[41] L. Gu and W. Ouyang, "Charitable giving, marketing ability and corporate performance[J]," Nankai Management Review, vol. 20, no. 2, pp. 94-107, 2017.

[42] S. Chen and J. Zhou, "The impact of corporate giving on innovation--an empirical study based on China's listed manufacturing companies[J]," Management Review, vol. 30, no. 11, pp. 57-67, 2018.

[43] C. Bohlmann, L. Krumbholz, and H. Zacher, "The triple bottom line and organizational attractiveness ratings: the role of pro-environmental attitude," Corporate Social Responsibility and Environmental Management, vol. 25, no. 5, pp. 912-919, 2018. 